\title{
A Brief Review on Sustainability Criteria for Building Materials
}

\author{
Alp Karakoç* \\ Department of Civil and Environmental Engineering, University of California Los Angeles, USA
}

Submission: June 17, 2017; Published: June 29, 2017

*Corresponding author: Alp Karakoç, Department of Civil and Environmental Engineering, University of California Los Angeles, Los Angeles, CA, USA, Email: akarakoc@ucla.edu

\section{Abstract}

Sustainability has been a decisive factor in selection of materials for the built environment due to increasing demand of materials despite the limited resources. The present study thus provides an insight into some measures of sustainable building material selection based on various rating systems and international standards.

Keywords: Sustainability; Built environment; Building material

\section{Introduction}

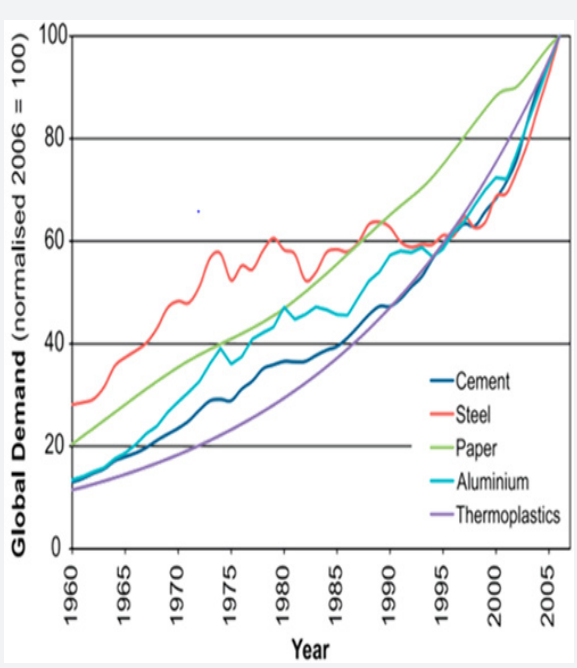

Figure 1: Global demand for various building materials.

In recent years, with increasing demand of energy-efficient and low-impact solutions for the built environment, sustainable design and materials selection methods have been game changers in the areas of architecture and construction. More than being a trend, the need for raw materials and decreasing amounts of resources urge engineers and architects to focus on the issue. As a general practice, the conventional building materials are categorized into three groups based on their raw materials: oil, e.g. polymers; ores, e.g. metals and ceramics; biomass, e.g. timber. Global demand to these materials and resources has quadrupled in the past 50 years, as depicted in Figure 1 [1]. According to The International Energy Agency, demand for materials will be at least double the current levels by 2050 [2].

In consideration to the severity of the issue, governmental agencies and research organizations have been developing and providing sustainable material rating systems, such as Leadership in Energy and Environment Design (LEED) in the US and Canada, and Building Research Establishment Environmental Assessment Method (BREEAM) in the UK. Also, there are available international standards including ISO 14040 Environmental Management, ISO 21930 Sustainability in building construction: Environmental declaration of building products, ISO 21931 Sustainability in building construction: Framework for methods of assessment of the environmental performance of construction works. These systems and standards have been gradually implemented into software for efficient built environment applications, e.g. ATHENA Impact Estimator for Buildings \& Eco Calculator and BEES Building for Environmental and Economic Sustainability.

In this review, individual (characteristics and life cycle of a material) and overall (material in the built environment) criteria for building materials are presented based on all these rating systems and standards. 


\section{Sustainability Criteria for Building Materials}

\section{Individual aspect: characteristics and life cycle of a building material}

In order to avoid the reduction of the resources and maintain the ecological balance, building materials selection should follow some generic qualitative rules. In the first place, the designer should investigate how harmful the material is to the environment and ask

I. Whether the selected material endangers wildlife and people.

II. Whether it is toxic to the environment.

III. Whether it is difficult to reuse or recycle.

Thus, the material selection should follow the priority list based on

I. The use of renewable materials, e.g. timber, hemp fibers or other growing substances,

II. If not, the use of recyclable materials, e.g. steel and aluminum, a good percentage of which can be recycled. The use of oil based building materials, e.g. plastics, should be minimized or avoided if possible.

In addition to this, energy consumption during material's life cycle should be also taken into account. The life cycle of a building material consists of several consecutive steps including

I. Raw material extraction,

II. Material transportation to the factory,

III. Production,

IV. Transportation to the construction site,

V. Construction,

VI. Operation and maintenance, and

VII. Recycling or disposal.

Table 1: Embodied energy and carbon emission of building materials.

\begin{tabular}{|c|c|c|}
\hline Material & $\begin{array}{c}\text { Energy } \\
(\mathbf{M}) / \mathbf{k g})\end{array}$ & $\begin{array}{c}\text { Carbon } \mathbf{e m i s s i o n} \\
\left(\mathbf{C O}_{\mathbf{2}} \mathbf{\text { kg }}\right)\end{array}$ \\
\hline $\begin{array}{c}\text { Concrete block } \\
\text { (Medium density) }\end{array}$ & 0.67 & 0.073 \\
\hline Cement mortar (1:3) & 1.33 & 0.208 \\
\hline Marble & 2 & 0.116 \\
\hline Bricks (common) & 3 & 0.24 \\
\hline Timber & 8.5 & 0.46 \\
\hline $\begin{array}{c}\text { Glue laminated } \\
\text { timber }\end{array}$ & 12 & 0.87 \\
\hline Stainless steel & 56.7 & 6.15 \\
\hline
\end{tabular}

The energy consumed in all these steps is called the total energy consumption of the material. Except the operational and maintenance step, the energy consumption of the material is called embodied energy, which is a decisive factor for sustainable building material selection [3]. In Table 1, embodied energy and carbon emission of some of the building materials are listed for a better understanding.

\section{Overall aspect: material in the built environment}

The sustainable building material selection has four main pillars, which are environmental performance, economic performance, building performance and material characteristics $[4,5]$. The first pillar, environmental performance of the material, has several measures, some of which are the fossil fuel consumption, global warming potential, acidification potential, human health respiratory effects, and atmospheric pollutant potential. The second pillar, economic performance of the material, mainly consists of procurement and maintenance costs. The third pillar, building performance, focuses on aesthetic aspect, lighting/acoustic/thermal comfort, and indoor air quality. The fourth pillar, material characteristics, is based on the energy consumption and carbon emission of the material during its life cycle, recycled content and proximity of the material to the construction site. All these pillars can be quantitatively evaluated, for instance, a more sustainable building material can be selected to construct the roof of an apartment building. These measures are compiled and listed in Figure 2.

\begin{tabular}{|l|l|}
\hline Environmental performance of the material & Building performance of the material \\
\hline Evaluated factors & Evaluated factors \\
\hline Fossil fuel consumption & $\begin{array}{l}\text { Aesthetic aspect } \\
\text { Global warming potential }\end{array}$ \\
\hline $\begin{array}{l}\text { Acightification potential } \\
\text { Human health respiratory effects }\end{array}$ & $\begin{array}{l}\text { Acoustic comfort } \\
\text { Thermal comfort }\end{array}$ \\
\hline Atmospheric pollutant potential & Indoor air quality \\
\hline Economic performance of the material & Material characteristics \\
\hline Evaluated factors & Evaluated factors \\
\hline Procurement costs & Energy consumption during its life cycle \\
\hline Maintenance costs & Carbon emission during its life cycle \\
\hline & Recycled content \\
\hline
\end{tabular}

Figure 2: Four main pillars of sustainable building material selection.

\section{Conclusion}

There is an increasing demand of energy-efficient and lowimpact solutions for the built environment. Thus, sustainable design and materials selection methods play critical role in the areas of architecture and construction. More than being a trend, the need for raw materials and decreasing amounts of resources urge engineers and architects to focus on the issue. In consideration to this, the present article provides a brief 
revision of some of the widely used rating systems and standards and compiles the pillars of sustainable building material selection criteria. The evaluated factors are aimed to guide the designers and engineers to decide sustainable solutions for built environment in an effective manner.

\section{References}

1. Allwood JM, Ashby MF, Gutowski TG, Worrell E (2011) Material efficiency: A white paper. Resources. Conservation and Recycling 55: 362-381.

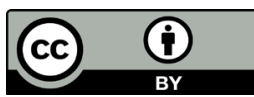

This work is licensed under Creative Commons Attribution 4.0 Licens DOI: 10.19080/JOJMS.2017.02.555579
2. Allwood JM, Cullen JM, Milford RL (2010) Options for achieving a 50\% cut in industrial carbon emissions by 2050 . Environmental Science and Technology 44(6): 1888-1894.

3. Hammond GP, Jones CI (2006) Embodied energy and carbon footprint database. Department of Mechanical Engineering University of Bath United Kingdom.

4. Froeschle LM (1999) Environmental Assessment and Specification of Green Building Materials. The Construction Specifier pp. 53-57.

5. Zhang YA (2012) Comprehensive Method for the Selection of Sustainable Materials for Building Construction. MSc Thesis.

\begin{tabular}{l} 
Your next submission with Juniper Publishers \\
will reach you the below assets \\
- Quality Editorial service \\
- Swift Peer Review \\
- Reprints availability \\
- E-prints Service \\
- Manuscript Podcast for convenient understanding \\
- Global attainment for your research \\
- Manuscript accessibility in different formats \\
( Pdf, E-pub, Full Text, Audio) \\
- Unceasing customer service \\
Track the below URL for one-step submission \\
https://juniperpublishers.com/online-submission.php \\
\hline
\end{tabular}

